\title{
Armed T cells with CAR for cancer immunotherapy
}

\author{
Yu-Quan Wei \\ State Key Laboratory of Biotherapy/Collaborative Innovation Center for Biotherapy, West China Hospital, Sichuan University, Chengdu \\ 610041, China
}

Received March 17, 2016

Citation: Wei, Y.Q. (2016). Armed T cells with CAR for cancer immunotherapy. Sci China Life Sci 59, 331-332. doi: 10.1007/s11427-016-5047-0

The development of genetic engineering has enabled the modification of stem cells and somatic cells. T cells exert immune responses against cancer cells. Efforts to redirect $\mathrm{T}$ cell specificity of a chimeric antigen receptor (CAR) to a desired antigen began in the 1990s (Gross et al., 1989; Kuwana et al., 1987). In 2006, the first clinical trial using carbonic anhydrase IX CAR-T cells to fight renal cancer was conducted (Lamers et al., 2006). Until 2011, Porter et al. exploited CD19 CAR-T to treat refractory/relapsed chronic lymphoid leukemia (Porter et al., 2011). Subsequently, trials using CD19 CAR-T to treat hematological malignancies, including acute lymphoid leukemia (Grupp et al., 2013), lymphoma (Brentjens et al., 2013; Lee et al., 2015), and even multiple myeloma (Garfall et al., 2015) revealed a positive response rate. In 2013, along with antibodies targeting immune checkpoints, CAR-T therapy reached a scientific breakthrough. A $93 \%$ complete response rate of CD19 CAR-T based cancer immunotherapy for acute lymphoid leukemia was reported at the most recent American Society of Hematology (ASH) meeting. Currently, more than 70 clinical trials are recruiting patients for CAR-Tbased cancer immunotherapy.

In China, CAR redirected T cells have been widely investigated (Wang et al., 2009; Wang et al., 2013). Several antigens recognized by CAR-T cells have been exclusively studied in China (Deng et al., 2015; Tang et al., 2014). Gao et al. completed preclinical studies of using glypican-3-specific CAR-T cells to treat hepatocellular carcinoma (Gao et al., 2014); these clinical trials are currently in

email: yqwei@vip.sina.com the recruitment stage. Han et al. registered the first CD138 CAR-T therapy for multiple myeloma (NCT01886976). Recent results from clinical trials in China showed substantial efficacy for treating hematological malignancies (Dai et al., 2015; Zhang et al., 2015; Zhang et al., 2016). To date, 29 clinical trials to evaluate the safety and efficacy of CAR-T therapy are being conducted in China and are expected to provide support for the safety and efficacy of CAR-T cells for further applications.

It is my great honor to guest-edit this special topic focused on CAR-T in Science China Life Science. In this issue, I present my understanding of the current status of CAR-T therapy in China and worldwide. To expand the therapeutic benefit for cancer patients in China, three aspects of CAR-T therapy must be addressed: (i) Regulatory guidelines specific for CAR-T therapy must be established to facilitate the commercialization of this cancer immunotherapy by pharmaceutical companies. (ii) Enhancing the therapeutic efficacy of CAR-T therapy for solid tumors is an important task. (iii) Enhancing the efficacy and safety of CAR-T therapy and searching for antigens specific to tumor cells is suggested, particularly using genome-wide sequencing to identify unique mutations related neo-antigens for CAR design. Once these aspects are resolved, CAR-T-based cancer immunotherapy is expected to provide multiple benefits to cancer patients.

Brentjens, R.J., Davila, M.L., Riviere, I., Park, J., Wang, X., Cowell, L.G., Bartido, S., Stefanski, J., Taylor, C., Olszewska, M., Borquez-Ojeda, O., Qu, J., Wasielewska, T., He, Q., Bernal, Y., Rijo, I.V., Hedvat, C., Kobos, R., Curran, K., Steinherz, P., Jurcic, J., Rosenblat, T., Maslak, 
P., Frattini, M., and Sadelain, M. (2013). CD19-targeted T cells rapidly induce molecular remissions in adults with chemotherapy-refractory acute lymphoblastic leukemia. Sci Transl Med 5, 177ra138.

Dai, H., Zhang, W., Li, X., Han, Q., Guo, Y., Zhang, Y., Wang, Y., Wang, C., Shi, F., Zhang, Y., Chen, M., Feng, K., Wang, Q., Zhu, H., Fu, X., Li, S., and Han, W. (2015). Tolerance and efficacy of autologous or donor-derived T cells expressing CD19 chimeric antigen receptors in adult B-ALL with extramedullary leukemia. Oncoimmunology 4, e1027469.

Deng, Z., Wu, Y., Ma, W., Zhang, S., and Zhang, Y.Q. (2015). Adoptive T-cell therapy of prostate cancer targeting the cancer stem cell antigen EpCAM. BMC Immunol 16, 1.

Gao, H., Li, K., Tu, H., Pan, X., Jiang, H., Shi, B., Kong, J., Wang, H., Yang, S., Gu, J., and Li, Z. (2014). Development of T cells redirected to glypican-3 for the treatment of hepatocellular carcinoma. Clin Cancer Res 20, 6418-6428.

Garfall, A.L., Maus, M.V., Hwang, W.T., Lacey, S.F., Mahnke, Y.D., Melenhorst, J.J., Zheng, Z., Vogl, D.T., Cohen, A.D., Weiss, B.M., Dengel, K., Kerr, N.D., Bagg, A., Levine, B.L., June, C.H., and Stadtmauer, E.A. (2015). Chimeric Antigen Receptor T Cells against CD19 for Multiple Myeloma. N Engl J Med 373, 1040-1047.

Gross, G., Waks, T., and Eshhar, Z. (1989). Expression of immunoglobulin-T-cell receptor chimeric molecules as functional receptors with antibody-type specificity. Proc Natl Acad Sci USA 86, 10024-10028.

Grupp, S.A., Kalos, M., Barrett, D., Aplenc, R., Porter, D.L., Rheingold, S.R., Teachey, D.T., Chew, A., Hauck, B., Wright, J.F., Milone, M.C., Levine, B.L., and June, C.H. (2013). Chimeric Antigen Receptor-Modified T Cells for Acute Lymphoid Leukemia. N Engl J Med 368, 1509-1518.

Kuwana, Y., Asakura, Y., Utsunomiya, N., Nakanishi, M., Arata, Y., Itoh, S., Nagase, F., and Kurosawa, Y. (1987). Expression of chimeric receptor composed of immunoglobulin-derived $\mathrm{V}$ regions and T-cell receptor-derived C regions. Biochem Biophys Res Commun 149, 960-968.

Lamers, C.H.J., Sleijfer, S., Vulto, A.G., Kruit, W.H.J., Kliffen, M., Debets, R., Gratama, J.W., Stoter, G., and Oosterwijk, E. (2006). Treatment of metastatic renal cell carcinoma with autologous
T-lymphocytes genetically retargeted against carbonic anhydrase IX: first clinical experience.. J Clin Oncol 24, e20-e22.

Lee, D.W., Kochenderfer, J.N., Stetler-Stevenson, M., Cui, Y.K., Delbrook, C., Feldman, S.A., Fry, T.J., Orentas, R., Sabatino, M., Shah, N.N., Steinberg, S.M., Stroncek, D., Tschernia, N., Yuan, C., Zhang, H., Zhang, L., Rosenberg, S.A., Wayne, A.S., and Mackall, C.L. (2015). T cells expressing CD19 chimeric antigen receptors for acute lymphoblastic leukaemia in children and young adults: a phase 1 dose-escalation trial. Lancet 385, 517-528.

Porter, D.L., Levine, B.L., Kalos, M., Bagg, A., and June, C.H. (2011). Chimeric antigen receptor-modified $\mathrm{T}$ cells in chronic lymphoid leukemia. N Engl J Med 365, 725-733.

Tang, X., Zhou, Y., Li, W., Tang, Q., Chen, R., Zhu, J., and Feng, Z. (2014). T cells expressing a LMP1-specific chimeric antigen receptor mediate antitumor effects against LMP1-positive nasopharyngeal carcinoma cells in vitro and in vivo. J Biomed Res 28, 468-475.

Wang, H., Wei, H., Zhang, R., Hou, S., Li, B., Qian, W., Zhang, D., Kou, G., Dai, J., and Guo, Y. (2009). Genetically targeted T cells eradicate established breast cancer in syngeneic mice. Clin Cancer Res 15, 943-950.

Wang, W., Ma, Y., Li, J., Shi, H.S., Wang, L.Q., Guo, F.C., Zhang, J., Li, D., Mo, B.H., Wen, F., Liu, T., Liu, Y.T., Wang, Y.S., and Wei, Y.Q. (2013). Specificity Redirection by CAR with human VEGFR-1 affinity endows $\mathrm{T}$ lymphocytes with tumor-killing ability and anti-angiogenic potency. Gene Ther 20, 970-978.

Zhang, T., Cao, L., Xie, J., Shi, N., Zhang, Z., Luo, Z., Yue, D., Zhang, Z., Wang, L., Han, W., Xu, Z., Chen, H., and Zhang, Y. (2015). Efficiency of CD19 chimeric antigen receptor-modified T cells for treatment of B cell malignancies in phase I clinical trials: a meta-analysis. Oncotarget 6, 33961-33971.

Zhang, W.Y, Wang, Y., Guo, Y.L., Dai, H.R., Yang, QM., Zhang, Y.J., Zhang, Y., Chen, M.X., Wang, C.M., Feng, K.C., Li, S.X., Liu, Y., Shi, F.X., Luo, C., and Han, W.D. (2016). Treatment of CD20-directed Chimeric Antigen Receptor-modified $\mathrm{T}$ cells in patients with relapsed or refractory B-cell non-Hodgkin lymphoma: an early phase IIa trial report. Signal Transduct Targeted Ther 1, 16002. doi:10.1038/ sigtrans.2016.2

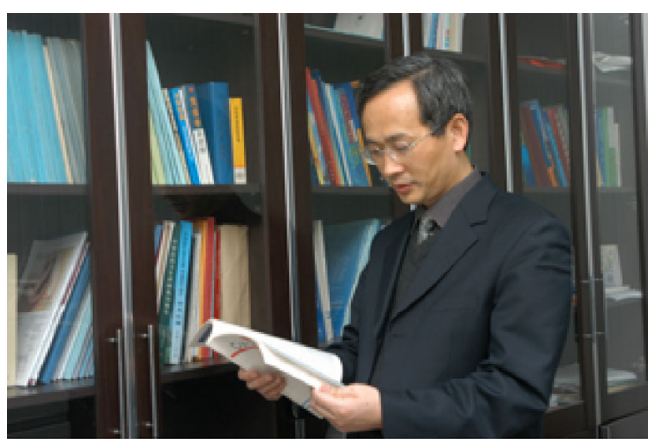

\section{Biographical Sketch}

Yu-Quan Wei, a well-known Professor of Oncology. He was born in Nanjiang, Sichuan Province, May 1959. He is a member of the China Academy of Science. He is the Director of the State Key Laboratory of Biotherapy and vice president of Sichuan University. Professor Wei focuses on using biotherapy for diseases, including cancers, autoimmune diseases, and cardiovascular diseases.

Open Access This article is distributed under the terms of the Creative Commons Attribution License which permits any use, distribution, and reproduction in any medium, provided the original author(s) and source are credited. 